\title{
INFLUENCE OF THIRD-PARTY FUNDS, CAR, NPF AND FDR TOWARDS THE RETURN ON ASSETS OF ISLAMIC BANKS IN INDONESIA
}

\author{
Risma Ayu Kinanti *) \\ Purwohandoko **)
}

\begin{abstract}
The purpose of this research is to analyze the influence of third party funds, capital adequacy ratio (CAR), non performing financing (NPF), financing to deposit ratio (FDR) Of return on assets (ROA) during period of 2008-2013 syariah banks in indonesia. About 3 syariah banks in indonesia was taken as sample for this research. The data used for this research were obtained from the data of Quarterly Published Financial Report Period 2008 up to 2013. The analysis technique used is Linear Regression that aims for estimating the relationships among variables. The results of $F$ test showing that Third Party Funds, CAR, NPF and FDR simultaneously influential to ROA. While The result of t-test showing Third Party and NPF has significant positif effect to ROA, CAR and FDR has a negative effect on ROA syariah banks in Indonesia
\end{abstract}

Keywords: ROA, Third Party Funds, CAR , NPF, FDR

\section{INTRODUCTION}

\subsection{Research Background}

Act number 21 of 2008 states that definition of Bank is a business entity that collects funds from people in the form of savings and distributes it to the people community in the form of credit and or other forms in order to improve people's living standards. Banking in Indonesia consists of sharia and conventional banking. Both have important role as intermediary in charge of collecting and also channeling funds to the people. In this matter, condition of banking can be seen from the performance achieved. Syofyan (2003) in Hutagalung (2013) states that profitability is the most appropriate indicator to measure bank performance. The measure of profitability used is the rate of return equity (ROE) for company in general and return on assets (ROA) in the banking industry. The ratio used to measure capital adequacy ratio in the banking sector that is used to calculate capital adequacy ratio (CAR). CAR is the ratio used to measure the adequacy of bank capital.

CAR is calculated by comparing the Modal Sendiri (Equity) with ATMR bank. In Sharia bank, decrease can be seen in the value of CAR in Islamic banks in 2008 to 2009 amounted to $2.04 \%$ and fell back in 2011 to 2012 at $2.09 \%$ while in conventional banking tend to be stable. In 2008, CAR of sharia commercial banks amounted to $12.81 \%$ further in 2009 of $10.77 \%$ resulting in decline of $2.04 \%$. In 2009 to 2010 rose $5.48 \%$ at $16.25 \%$. This number is stable until 2011 . The stable of CAR in 2010 to 2011 due to some of parent banks (bank induk) injected funds into sharia banks to fulfill capital adequacy ratio. In 2011 to 2012 back down $1.45 \%$. Then, only increased by $0.15 \%$ in 2013 . Analysis on Sharia Commercial banks shows that there is a decrease in CAR value in deposits (DPK) positions increased from the previous year. If seen from Sharia Commercial banks DPK rate in 2008 to 2009, an increase in DPK rate which is from 36.852 to rate of 52.271 has occured.

If DPK rate rises then CAR rate should also rises, but not in the sector of Sharia Banks in 2008 to 2009 even in 2010 until now rise in DPK still continue even there is fluctuations in CAR rate on Sharia Banks. The increase in DPK rate is not in line with ROA rate of Sharia Bank. If DPK rate rises, then ROA rate increases. But ROA in Sharia Bank tends to fluctuate.

\subsection{Research Problem}

Research problem that proposed by researcher in explaining those background can be described in two statements:

1. Simultaneously, there is an effect between between third party funds, CAR, NPF, and FDR towards ROA Islamic Banks in Indonesia 
2. Partially, there is an effect between between third party funds, CAR, NPF, and FDR towards ROA Islamic Banks in Indonesia

\subsection{Research Purpose}

This research aims to examines the relationship effect both simultaneously and partially between third party funds, CAR, NPF, and FDR towards ROA Islamic Banks in Indonesia.

\section{THEORETICAL FRAMEWORK AND HYPHOTESIS DEVELOPMENT}

\subsection{Previous Research Studies}

A different result of research proposed by Sri, et al. (2013) that the DPK does not affect ROA due to problem loans so that funds collected from third parties can not be maximally obtained by the bank. The urgency of CAR use in this study is indicated by variations results of several studies in relation to financial performance. Widyanto (2012) states that if the value of CAR increases then there is a decrease in profits. Eung (2013) stated that CAR statistically did not have a significant effect on ROA because the banks that operate does not optimize the existing capital. This occurs due the regulations of the Bank of Indonesia that require CAR amounted to $8 \%$ for minimum that caused banks always try to keep CAR owned according to the existing provisions.

Related to NPF variables, result of research submitted by Sri, et al. (2013) states that NPF has a positive effect on performance. If NPF value is high, it shows that the value of loan disbursement by the bank is high too, so it affects the financial performance. If there is large number of problem loans, it tends to decrease profitability. Different results shown by Rafelia (2013) states that the NPF has a negative effect on ROA. However, the NPF has a positive effect if performance is proxied with ROE. Number of credit or financing problem can affect NPF.

The urgency of FDR usage in this research is shown by Riyadi and Agung research variation (2014) stated that FDR has positive effect on ROA. This happens because when the channeling of funds to the people is high, then the return will also high and will have an impact on earnings obtained by the banks, the results are in accordance with the theory of stewardship. Stewardship theory can be understood in the channeling of banking institution financing. Sharia Banks as principal which entrust customers as stewards to manage funds ideally able to accommodate all the interests of all parties. While other researchers such as Nurkhosidah (2013) in Dewi (2010) suggest that FDR has a negative effect on ROA. The results showed that FDR and PPAP had no significant effect on ROA. BOPO and NPF have a significant negative effect on Sharia bank ROA.

The existence of phenomenon of gap and diversity of argument (research gap) is the reason for existing of influence research of third party funds (DPK), capital adequacy ratio (CAR), non performing financing (NPF), financing to deposit ratio (FDR) over return on assets (ROA) of Sharia Banks in Indonesia during the periode of 2008-2013.

The Signal Theory suggests about how a company should signal the users of financial statements. This signal is information about what has been done by management to realize the desire of the owner (Jogiyanto, 2000: 39). The signal theory in this study is used to explain the effect of NPF and CAR on ROA.

\subsection{Theoretical Framework}

\subsubsection{Signal Theory}

Signal theory argued about how should a company give signals to users of financial statements. This signal in the form of information about what has been done by management to realize the wishes of the owner (Jogiyanto, 2000). Theory of the signal in this research is used to describe the influence of the NPF, and CAR against ROA. 


\subsubsection{Pecking Order Theory}

This theory proposed by Donaldson in 1961. If it is assumed that company's goal is to minimize the total cost of funding then choose the instruments and capital structure of the company depending on the constraints faced. These costs include direct and indirect costs. The direct cost is a cost that requires the company to pay explicitly relating to the money used to arrange funding from the funder. This fee includes a number of special costs incurred for debt or equity compensation in the form of mark-up in murabaha, internal rate of return in ijarah, share profit and loss in mudlarabah and musharaka. This theory explains the relationship between FDR and ROA

\subsubsection{Stewardship Theory}

Stewardship theory is a theory proposed by Donaldson and Davis. Sharia Banks that entrust clients as Steward to manage funds that should be able to accommodate the interests between banks and customers whose base their services on behavior that is able to work together within the organization (Riyadi and Agung, 2014). This theory is related to the Fund obtained then distributed by Sharia banking financing products that related to ROA value.

\subsubsection{Financial Performance}

Financial performance is the result achieved by bank in managing its resources owned to achieve its objectives. While ratio used is Return on Assets (ROA). For management or other parties, high profitability is more important than a big profit. Return on Assets (ROA) focuses the company's ability to gain earnings in operations. The higher ROA of a bank, the greater the level of profit achieved by bank and the better bank's position in terms of asset use (Hutagalung, 2013). A positive Return on Assets (ROA) shows that from total assets used to operate, the company is able to provide profits for the company. In the other hand, negative Return on Assets indicates that from total assets used, companies suffer a loss (Sulistyaningrum, 2013). Munawir (2001) explains that profitability or rentability is used to measure the efficiency of capital use in a company by comparing profit with capital used in operation, therefore large profits do not guarantee or is not a measure that the company is rentable.

\subsubsection{Third-Party Funds (DPK)}

Muljono (2006) in Hutagalung (2013) defines third party funds as funds collected from these communities will be used for funding the real sector through lending. Third party funds in Sharia banking is Giro justified by Sharia which is giro demand based on mudharabah and wadi'ah principle, saving based on Wadi'ah contract or investment fund based on mudharabah contract or other contract which is not contradictory to Sharia principle which withdrawal by specific terms and conditions and can not be withdrawn by check and / or other tools equivalent to the instrument and deposits justified by Sharia which is saving based on the principles of mudaraba and wadi'ah.

\subsubsection{Capital Adequacy Ratio (CAR)}

Keovongvichith (2012) Based on the international banking regulators (the Basel Committee for Banking supervision), the minimum capital adequacy ratio (CAR) is 8 percent (in accordance with international banking Regulatory minimum CAR is $8 \%$. This ratio can be formulated: (Bank Capital/Risk Weighted Assets) x 100\%. Islamic banking assets are divided over the assets funded by private equity and liabilities or debts (wadi'ah or qard) funded assets and account for the results i.e. mudharabah (mudharabah mutlaqah are recorded in the balance sheet and the mudharabah muqayyadah which is recorded in the administrative account).

\subsubsection{Non Performing Financing (NPF)}

The dictionary of Bank of Indonesia shows that non performing financing (NPF) is a problematic financing consists od non-performing clarification, doubtful. The amount of NPF allowed in Bank Indonesia is 5\%, if exceeding 5\% will affect the rating of the bank health concerned that will reduce the value of score obtained. Financing risk increases, loan interest will 
increase as well. Meanwhile, in the Islamic economy the banking sector does not recognize the instrument of interest, the Islamic financial system implements a system of profit and loss sharing that has set the rate of profit in advance. (Sulistyaningrum, 2013).

\subsubsection{Financing to Deposit Ratio (FDR)}

Financing to deposit ratio is a measuring instrument to measure financing volume so that this FDR ratio can show bank health in providing financing. The results of Pramuka research (2010) in (Sulistyaningrum, 2013) showed that FDR has significant and positive in the direction of profitability (ROA) of Sharia Bank. That means, the higher this ratio indicates that the more optimal intermediary function run by Islamic banks, thereby increasing profitability.

\subsubsection{DPK, CAR, NPF, FDR and ROA}

According to Purwohandoko et al. (2014) The definition of CAR is the ratio comparison between profit after tax with total assets used to measure the ability of companies in generating return on assets used in certain periods. Widyanto (2012) states that if the value of CAR increases then there is a decrease in profits. Eung (2013) stated thzt CAR statistically does not have a significant effect on ROA because the banks that operate does not optimize the existing capital. So CAR is used to determine the ability of banks to generate profits. In Signal Theory it is explained that company will provide a signal so that users of financial statements can obtain a signal about the financial performance of the company itself.

The ratio of non-performing financing (NPF) is a non performing financing consisting of nonperforming clarification, doubtful. NPF has a positive effect if performance is proxied with ROE. Lagre amount of credit or non-performing financing can affect the NPF which will also affect the bank's ROA itself. In accordance with the Theory of Signals by looking at the NPF numbers of a bank, the users of financial statements will know the amount of financing that is smooth and not smooth so that users of financial statements will get a signal about the financial performance of the bank itself.

The financing to deposit ratio is a measuring instrument to measure the volume of financing so that this FDR ratio can show the health of banks in providing its financing. Riyadi and Agung (2014) stated that FDR has a positive effect on ROA. This happens because when the channeling of funds to the people is high, then it will get a high return too and will have an impact on the profits obtained by the bank. While other researcher, Nurkhosidah (2013) in Dewi (2010) suggests that FDR has a negative effect on ROA.The results showed that FDR had no effect significantly to ROA Islamic banks. Pecking Order theory explains the companies tend to choose use the funds to conduct its internal funding. Islamic banking use Microsoft's internal funds in finance. The measurement of the volume of financing used numeric assessment of FDR. With the increase in numbers of the FDR will certainly happen increases the number ROA. The existence of a health assessment of banking will provide convenience for the users of the services of banks and investors.

\subsection{Hyphotesis}

Researcher proposed five hyphotesis in answering research problem :

$\mathrm{H}_{1}$ : DPK, CAR, NPF, FDR has an effect towards Return On Assets (ROA) of Syariah Bank in Indonesia during 2008-2013 periods simultaneously.

$\mathrm{H}_{2}$ : Third-Party Funds (DPK) has a positive effect towards the Return On Assets (ROA) of Syariah Bank in Indonesia during 2008-2013 periods.

$\mathrm{H}_{3}$ : Capital Adequacy Ratio (CAR) has a positive effect towards the Return On Assets (ROA) of Syariah Bank in Indonesia during 2008-2013 periods.

$\mathrm{H}_{4}$ : Non Performing Financing (NPF) has a negative effect towards the Return On Assets (ROA) of Syariah Bank in Indonesia during 2008-2013 periods.

$\mathrm{H}_{5}$ : Financing to Deposit Ratio (FDR) has a positive effect towards the Return On Assets (ROA) of Syariah Bank in Indonesia during 2008-2013 periods. 


\section{RESEARCH METHOD}

\subsection{Research Design}

Type of this research is quantitative descriptive research. The methods used in this study was the quantitative approach to population is the generalization of the object/subject who has certain qualities and characteristics that are applied by researchers in order to learn and then drawn the conclusion (Sugiyono, 2012).

\subsection{Population and Sample}

The population in this research is the Islamic bank is registered in the financial services authority as much as 12 companies. Sampling is that part of the sum of the characteristics possessed by the population. Sampling technique is used that is purposive sampling. As for the criteria used to select the sample that is included in the listed Bank public Bank Syariah recorded in Bank Indonesia Directorate during the research period, the Bank is a Bank registered in the Public Sharia Financial Services Authority Indonesia during the research period. Has published financial statements beginning in 2008. Required data is balance sheets report, profit/loss report, preparation report and calculation of the minimum capital ratio of finance of Islamic Banks that registered in the Islamic Bank OJK in 2008-2013. The year of 2013 was chosen as the end of the research because this research using the latest data.

\subsection{Research Variables}

The dependent variables used in this study is the ROA. Meanwhile the independent variable used is the DPK, CAR, NPF and FDR. Return on assets (ROA) ratio is a comparison between the profits after taxes (EAT) with total assets that are used to measure the company's ability in generating return on assets to be used in a certain period. Purwohandoko, et al (2014) measures the value of ROA:

$$
\text { ROA }=\frac{\text { Earning After Tax }}{\text { Total Assets }}
$$

Third party funds are funds collected by the bank. In third-party funds Islamic banks seen from the balance sheet report in example mudharabah, wadi'ah. Yuliana (2009) stated that DPK can be measures by:

\section{Tab. Mudharabah + GiroWadi’ah + Deposito Mudharabah}

Capital adequacy ratio car is a bank or is the ability of banks in the capital. According to Muljono (1999) in Hutagalung (2013) measures the CAR including:

$$
\mathrm{CAR}=\frac{\text { Modal Bank }}{\text { ATMR }} \times 100 \%
$$

NPF is the ratio between the total credit which is not smooth (NPF) to the total financing. According to Riyadi and Akbar (2014) measure the NPF:

$$
\mathrm{NPF}=\frac{\mathrm{NPF} \text { total pembiayaan }}{\text { total pembiayaan }} \times 100
$$

FDR is a measuring instrument used to measure the volume of financing so that the ratio of FDR this can show the health of banks in providing financing. According to Riyadi and Akbar (2014) measurement of FDR by way of:

$$
\text { FDR }=\frac{\text { FDR total pembiayaan }}{2 \text { aTotal DPK }}
$$




\subsection{Research Framework}

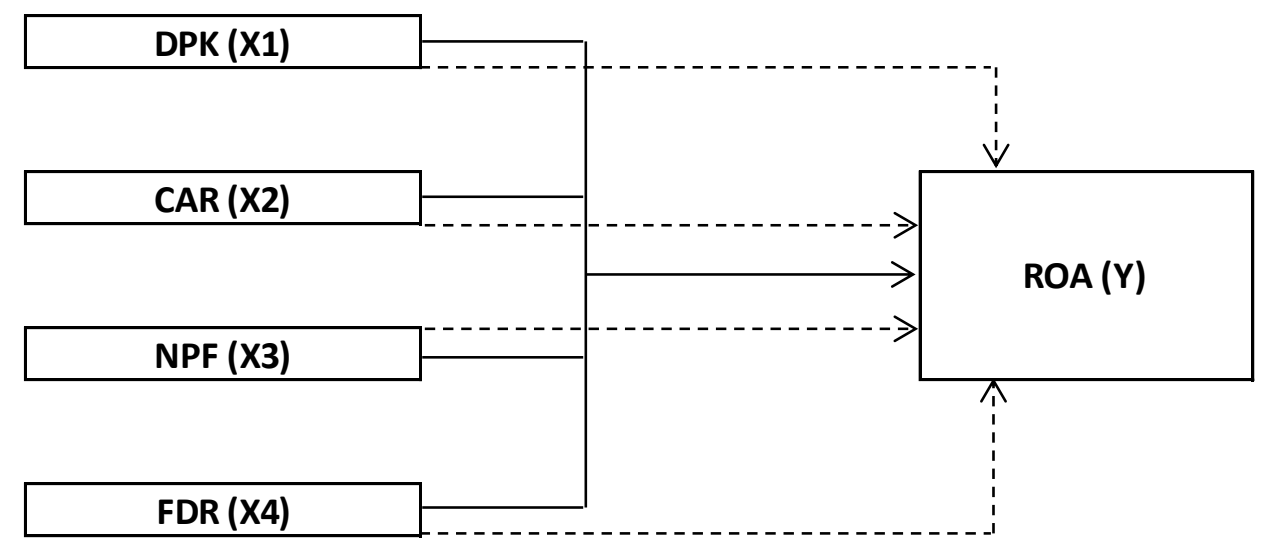

Picture 1 Research Framework

\subsection{Type of Data And Sampling Method}

Researcher uses purposive sampling as their sampling technique. The sample of this research populations is Islamic (Sharia) Banks that listed in Bank Indonesia Directorate during the research period Methods of analysis used in this study is to conduct a quantitative analysis in the calculations using statistical methods that helped with statistical data processing program that is SPSS 18. The methods used are descriptive analysis, test the assumption of simultaneous significance tests, classic ( $F$ testing), test the significance of individual parameters (test statistic $t$ ). and the determination of the coefficient of R2. Model testing performed by linear regression. Regression equation used in this research can be formulated as follows:

$$
Y=a+\beta_{1} X_{1}+\beta_{2} X_{2}+\beta_{3} X_{3}+\beta_{4} X_{4}+e
$$

\section{Description:}

$$
\begin{aligned}
& \mathrm{Y}=\mathrm{ROA} \\
& \mathrm{a}=\text { Constant } \\
& =\text { Coefficient of regression } \\
& \text { X } 1=\text { DPK } \\
& \text { X } 2=\text { CAR } \\
& \text { X } 3=\text { NPF } \\
& \text { X } 4=\text { FDR } \\
& \text { e }=\text { Factor Bullies }
\end{aligned}
$$

\section{RESEARCH RESULT AND ANALYSIS}

\subsection{Hypothesis Testing}

As mentioned in data analysis above, the result of multiple regression can be described below

Table 1 Multiple Regression Results

\begin{tabular}{|l|l|l|}
\hline Variables & B & t sig \\
\hline DPK & 5,605 & 0,000 \\
\hline CAR & $-0,141$ & 0,001 \\
\hline NPF & 8,97 & 0,001 \\
\hline FDR & 0,719 & 0,000 \\
\hline Adjusted R Square & 0,290 & \\
Correlation Coef (R) & 0,548 & \\
F Test & 0,000 & \\
\cline { 1 - 2 } &
\end{tabular}


Based on Table 1, we can concluded that DPK, CAR, NPF, FDR statistically has a significant and simultaneously ( $F$ test siginifance value is below 0.05) effect towards Return On Assets (ROA) of Syariah Bank in Indonesia during 2008-2013 periods (H1 accepted). This research also support hyphotesis 2 and 4 (siginifance value is below 0.05) proposed that third-party funds (DPK) and financial deposit ration has a positive effect against the Return On Assets (ROA) of Syariah Bank in Indonesia during 2008-2013. Unfortunately, this research failed to prove H3 and H4.

\subsection{Research Discussion}

\subsubsection{Influence Third-Party Funds towards ROA}

The test results shows that there are influences between variables of third party Funds against ROA public Bank Syariah Indonesia in the period 2008-2013. The existence of the research results presented by Rohaeni (2010) showed a positive influence among third-party funds (DPK) against the return on assets (ROA). Research tells us that the income from the credit channeling activities provide the most influence on the achievement of profit. The addition of a number of early financing of the numbers shall be - so that clients know the number of returns and have the right not to approve or even approve it.

Stewardship Theory describes a situation where manager is not motivated by individual goals but aimed it more to the results for the organization's interest. This theory is understood in banking financing products. Sharia banks that entrust clients as Steward to manage funds that should be able to accommodate the interests of banks and customers whose base their services at behavior that is able to work together within the organization (Riyadi and Agung, 2014).

This kind of accommodating the interests of banks with customers in Sharia banks can be seen from the financing distributed to customers that always preceed by the agreement/contract. Thus, calculation of financing return given will not be approved so as not to burden the customer. This certainly shows the role of Sharia banks as steward to its customers. Rohaeni (2010) shows a positive influence between Third Party Fund (DPK) on Return On Assets (ROA). The study explains that income from credit distributing activities gives the most influence to the achievement of profit.

\subsubsection{The Influence of the CAR against ROA}

The value of CAR demonstrates the ability of banks to manage capital. In theory if the number CAR rise certainly demonstrates the ability of banks capable of managing its capital. But in channeling capital Islamic Banks that is used in the financing system for results makes his financing results sometimes smaller than channelling their funds. So if numbers CAR rise will reduce the profits of the bank. Because capital is more used in covering the financing that is not smooth. Widyanto (2012) stated that if the value of the CAR rise then occurs a decrease in profits.

\subsubsection{The Influence of Non Performing Financing against ROA}

The influence of the variable given by the NPF against ROA is positive. This happens because the average value of the NPF Bank syariah is $0.001 \%$, still on the amount standrat of NPF required by Bank Indonesia. Therefore the increases NPF does not result in a decrease in ROA allowance because the value of Productive Assets (PPAP) is still able to cover bad debt. Banking profits can still increase with the NPF is high because the source of interest earnings as fee based income relative high. PT Bank Syariah Mandiri (BSM) noted the achievement of revenue-based fee (fee based income) year end $2011 \mathrm{Rp} 1.08$ trillion, up 90.94\% compared to achieve significant end 2010 worth Rp 567billion (http://www.syariahmandiri.co.id/2012/04/fee-based-income).

Other research also suggested Prasnanugraha (2007) do research analysis of the influence of ratio-financial ratio on performance of public Banks in Indonesia. NPL figures shows positive signs that can be explained in that year even though the value remains high ROA NPL is also high.

\subsubsection{The Influence of Financing to Deposit Ratio against ROA}

If Islamic banking less in obtaining financing, will certainly affect the numbers return earned. One of the reasons of the lack of financing issued i.e. lack of customer knowledge about Islamic 
banks make not enough clients perceive the system in Islamic banking. While the research of Nurkhosidah (2013) in the Goddess (2010) suggests that FDR effect negatively to ROA. The results showed that FDR had no effect significantly to ROA Islamic banks. So if the value of the FDR to rise but not smoothly financing figures are also rising, will certainly influence negatively to ROA on Sharia.

\subsubsection{The influence of DPK, CAR, NPF, FDR towards Return On Assets}

Third party funds (DPK), CAR, non performing financing (NPF) and financing to deposit ratio (FDR) together have an influence on return on assets (ROA). The higher CAR achieved by a bank shows better bank performance because the bank is able to cover its decline in assets as a result of bank losses. If the CAR is below $8 \%$ then the bank has no opportunity to provide credit. If the Bank no longer has the opportunity to distribute credit would greatly affect the bank's ROA rate itself. Beside CAR which also greatly affect the ROA is ratio of NPF which shows the ability of bank management in managing non-performing loans provided by banks. Ability in managing nonperforming loans is very important because it is closely related to the return value obtained by the bank. Besides NPF the FDR ratio is also very important. The higher the FDR then the bank is able to channel its credit effectively which will certainly increase the bank's profit

\section{RESEARCH CONCLUSION, LIMITATION, AND RECOMMENDATION}

\subsection{Conclusion}

Based on the results of research and discussion, it can be concluded that the third party funds (DPK), capital adequacy ratio (CAR), non performing financing (NPF) and financing to deposit ratio (FDR) all together have an influence on the return on assets (ROA). In Sharia Commercial Bank in Indonesia in in the period of 2008-2013, Third Party Fund has positive effect on ROA of Sharia Commercial Bank in Indonesia in the period of 2008-2013, capital adequacy ratio (CAR) have negative effect on ROA of Sharia Commercial Bank in Indonesia in the period of 2008-2013, non performing financing NPF) positively influences on ROA of Bank Syariah in Indonesia in the period of 2008-2013, financing to deposit ratio (FDR) have negative effect on ROA of Sharia Commercial Bank in Indonesia in the period of 2008-2013. Banking companies are expected to penalize the financial ratios that can be a reference bank in order to be able to identify problems, conducting appropriate follow up improvements. If there is an increase in the DPK number but the NPF also rises, it indicates the ineffectiveness of the loan issued by the bank.

\subsection{Limitation}

Researchers are expected to conduct further research regarding a result of existing research on NPF numbers that have a positive effect on ROA.

\subsection{Recommendation}

It is expected that the next research will be continued in the coming period considering the rapid development of Sharia banking. For investors with a long-term investment in banking, it is suggested to consider the ratios described earlier. Viewing the amount of Third Party Funds, we can see the value of DPK because the rise of DPK number will affect the amount of financing issued by Sharia Bank. Next, look at the value of capital adequacy owned by CAR. In order for potential investors to know the number of non-current loans viewed from the NPF numbers and the last FDR numbers used to know the volume of financing. By looking at these ratios, investors can certainly choose the right type of investment in sharia banking.

\section{REFERENCES}

Eng, Tan Sau. (2013). The Effect of NIM, Operational Efficiency Ratio (BOPO), LDR, NPL \& CAR Toward ROA Of International And National Public Listed Banks For The Period Of 2007 - 2011. Jurnal Dinamika Manajemen, Vol. 1, No.3, Hal.1 , ISSN: 2338 - 123X. 
Jurnal Ilmiah Bidang Akuntansi dan Manajemen (JEMA) Vol. 14 No. 2 (2017)

http://riset.unisma.ac.id/index.php/jema

Ghozali, Imam. (2013). Aplikasi Analisis Multivariate Dengan Program SPSS 21, Edisi 7. Semarang : Badan penerbit Universitas Diponegoro.

Hasan, Nurul Ichsan. (2014). Perbankan Syariah. Jakarta : Referensi.

Hutagalung, Esther, Djumahir, Kusuma. (2013). Analisa Rasio Keuangan terhadap Kinerja Bank Umum di Indonesia. Jurnal Aplikasi Manajemen (Online), Vol.11, No.1. Hal.6-9

Jogiyanto. (2000). Teori Portofolio dan Analisis Investasi Edisi 2. Yogyakarta : Universitas Gajah Mada.

Keovongvichith, Phetsathaphone. (2012). An Analysis of the Recent Financial Performance of the Laotian Banking Sector during 2005-2010. International Journal of Economics and Finance, Vol. 4, No. 4; Hal. 148

Munawir. (2004). Analisa Laporan Keuangan. Yogyakarta : Penerbit Liberty.

Najmudin. (2011). Manajemen Keuangan dan Aktualisasi Syariah Modern. Yogyakarta : Andi Offset.

Purwohandoko. Asandimitra, Nadia. Isbanah, Yuyun. Kautsar, Achmad. (2014). Dasar-Dasar Manajemen Keuangan (Teori, Aplikasi dan Kasus). Surabaya : Unesa University Press.

Rafelia, Tyas. (2013). Pengaruh CAR, FDR, NPF, dan BOPO terhadap ROE Bank Syariah Mandiri Periode Desember 2008-Agustus 2012. Diponegoro Journal Of Accounting (Online), Vol. 1, No.1, Hal 1-9.

Republik Indonesia. (2008). Undang-Undang No. 21 Tahun 2008.

Riyadi,Slamet. Yulianto,Agung. (2014). Pengaruh Pembiayaan Bagi hasil,Pembiayaan Jual Beli, Financing to Deposit Ratio, dan Non Performing Financing terhadap Profitabilitas Bank Umum Syariah di Indonesia. Acoounting Analysis Journal, Vol. 3, No. 4, Hal.6-9 ISSN 22526765 .

Sri, Anastasya, Ratna Anggraini, Etty Gurendrawati dan Nur Amalia Hasanah. (2013). The Influence of Third-Party Funds, Car, Npf and Roa Against The Financing of A General Sharia-Based Bank in Indonesia. The 2013 IBEA, International Conference on Business, Economics, and Accounting (Online).

Widyanto, Eko Adi. (2012). Analisis Tingkat Kesehatan dan Kinerja Keuangan Bank dengan menggunakan Metode CAMEL (Studi Kasus pada PT. Bank Mega Syariah Indonesia Periode 2008-2010). Jurnal Eksis .Vol.8, No.2, Hal. 1-6.

*) Risma Ayu Kinanti, Surabaya State University

**) Purwohandoko, Surabaya State University 